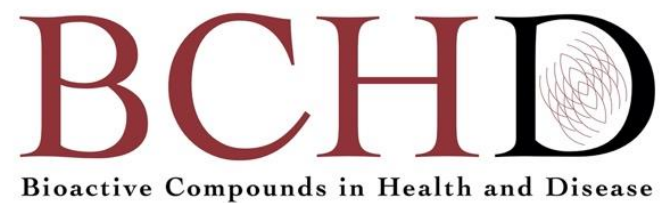

\title{
Bioactive compounds in functional food and their role as therapeutics
}

\section{Neelakanta Pillai Padmakumari Soumya ${ }^{1 *}$, Saraswathy Mini ${ }^{1}$, Shali Kochuvelickakathu Sivan ${ }^{1}$, Sukanta Mondal²}

${ }^{1}$ Department of Biochemistry, University of Kerala, Karyavattom Campus, Thiruvananthapuram, India- 695581; ${ }^{2}$ ICAR- National Institute of Animal Nutrition and Physiology, Bengaluru, India-560030

*Corresponding author: Dr. N.P. Soumya, MVSc, PhD, CCLAS, Department of Biochemistry, University of Kerala, Karyavattom Campus, Thiruvananthapuram, India- 695581

Submission Date: March 5 ${ }^{\text {th }}, 2021$; Acceptance Date: March 26 ${ }^{\text {th }}, 2021$; Publication Date: March $29^{\text {th }}, 2021$

Please cite this article as: Soumya N.P., Mini S., Sivan S., Mondal S. Bioactive compounds in functional foods and their role as therapeutics. Bioactive Compounds in Health and Disease 2021. 4(3); 24-39. DOI: https://www.doi.org/10.31989/bchd.v4i3.786

\section{ABSTRACT \\ Bioactive food ingredients are non-essential substances found in foods that can modulate one or more metabolic processes, resulting in enhanced health. Functional diets have attracted more critical than ever as an alternative to conventional treatments of many diseases. The medicinal potential of functional foods and nutraceuticals are due to some unique functional groups produced due to food metabolism and their molecular BIOLOGICAL PROPERTIES OF BIOACTIVE COMPOUNDS variants. Phytochemicals are biologically active, naturally occurring chemical compounds in plants with various biological properties and therapeutic benefits. While functional foods and natural bioactive compounds have}


been used as conventional medicines to treat chronic diseases for decades, recent scientific findings identify functional foods' health advantages and present the basic mechanisms of their behaviors. Phytochemicals have essential bioactive roles in the prevention and treatment of oxidative and inflammatory diseases. Plant-derived bioactive compounds can help suppress inflammation by inhibiting oxidative damage and communicating with the immune system. Many bioactive components are capable of binding to intestinal tract toxins or carcinogens. These bioactive peptides control diet-related medical conditions such as obesity, cardiovascular diseases, and other metabolic diseases. Various bioactive compounds in common food and their therapeutic role is discussed in this review.

Keywords: Functional food, phytochemicals, bioactive peptides, therapeutic effects.

CFFC 2021. This is an Open Access article distributed under the terms of the Creative Commons Attribution 4.0 License (http://creativecommons.org/licenses/by/4.0)

\section{INTRODUCTION}

Bioactive compounds from food have been investigated to elucidate their biological activity in the human body systems, and functional foods have emerged as promising options for preventing and treating various diseases. Scientists estimated that unhealthy lifestyles and stress have a combined impact on the immune system, raising the risk of multiple cardiovascular disorders, cerebrovascular conditions, infections, and diseases like cancer. In response to the rising awareness of diet's influence on health, demand for functional foods and nutraceuticals has increased significantly. For their anti-microbial roles and humoral and cell-mediated immune functions, specific bioactive components have been integrated as additives in functional foods, nutraceuticals, and pharmaceuticals, where their biological activities can assist in disease control and prevention. Thus, some food ingredients' therapeutic potential has become a significant concern for physicians, food producers, researchers, and consumers. It seems that today's world is coming to clasps with the ancient excerpt, 'Let food be the medicine and medicine be the food' more than ever before.

Functional foods are any natural or refined food that has health benefits and disease prevention activities above its simple nutritional value. These different nutritional constituents in foods are the bioactive compounds that usually exist in limited concentrations. Nutraceuticals are foods and food supplements that contain bioactive compounds in a standardized form with therapeutic properties. The medicinal potential of functional foods and nutraceuticals are due to some unique functional groups produced due to food metabolism and their molecular variants. Components of functional foods are usually present in different forms, such as glycosylated, esterified, thiolylated, or hydroxylated forms. In particular, bioactive food ingredients are believed to be found mainly in plant foods, such as whole grains, fruits, and vegetables. Similarly, animal products such as milk, fermented milk products, and cold-water fish also contain bioactive components such as probiotics, conjugated linolenic acid, longchain omega-3 polyunsaturated fatty acid, and 
bioactive peptides. Bioactive nutritional factors often have several metabolic activities that cause beneficial effects on many diseases.

Bioactive food components from plant sources: Phytochemicals in plants are biologically active, naturally occurring chemical compounds with therapeutic benefits beyond those attributed to macronutrients and micronutrients. These compounds are considered secondary metabolites in plants with biological properties such as antioxidant activity, anti-microbial activity, enzyme detoxification regulation, immune system modulation, reduced platelet aggregation, hormone metabolism, and anticancer property [98].

Depending on their function in plant metabolism, phytochemicals are graded as primary or secondary constituents (Figure 1). More than 4,000 phytochemicals have been catalogued, and about 150 phytochemicals have been studied in detail [5]. The main primary elements include carbohydrates, amino acids, nucleic acid proteins, chlorophyll, purines, and pyrimidines. The other secondary constituents are alkaloids, terpenes, flavonoids, lignans, steroids, curcumin, saponin, flavonoids, glucosides, and phenolics $[40,98]$.

It is rare to find one class of bioactive food components within a plant singly. Instead, these are found in mixtures. Fruits, legumes, whole grains, nuts, seeds, mushrooms, herbs, and spices encompass a wide variety of dietary phytochemicals [73]. Likewise, broccoli, cabbage, onions, garlic, whole wheat bread, bananas, oranges, cherries, strawberries, raspberries, beans, legumes, and soy foods are also good sources of phytochemicals [78]. Differences in its level may vary from plant to plant depending on the variety, processing, cooking, and growing conditions [61].

Bioactive compounds such as omega-3 fatty acids (n-3 FA), plant sterol esters (PSE), and phenolic compounds $(\mathrm{PHC})$ are natural molecules with great potential to reduce the atherosclerosis burden by

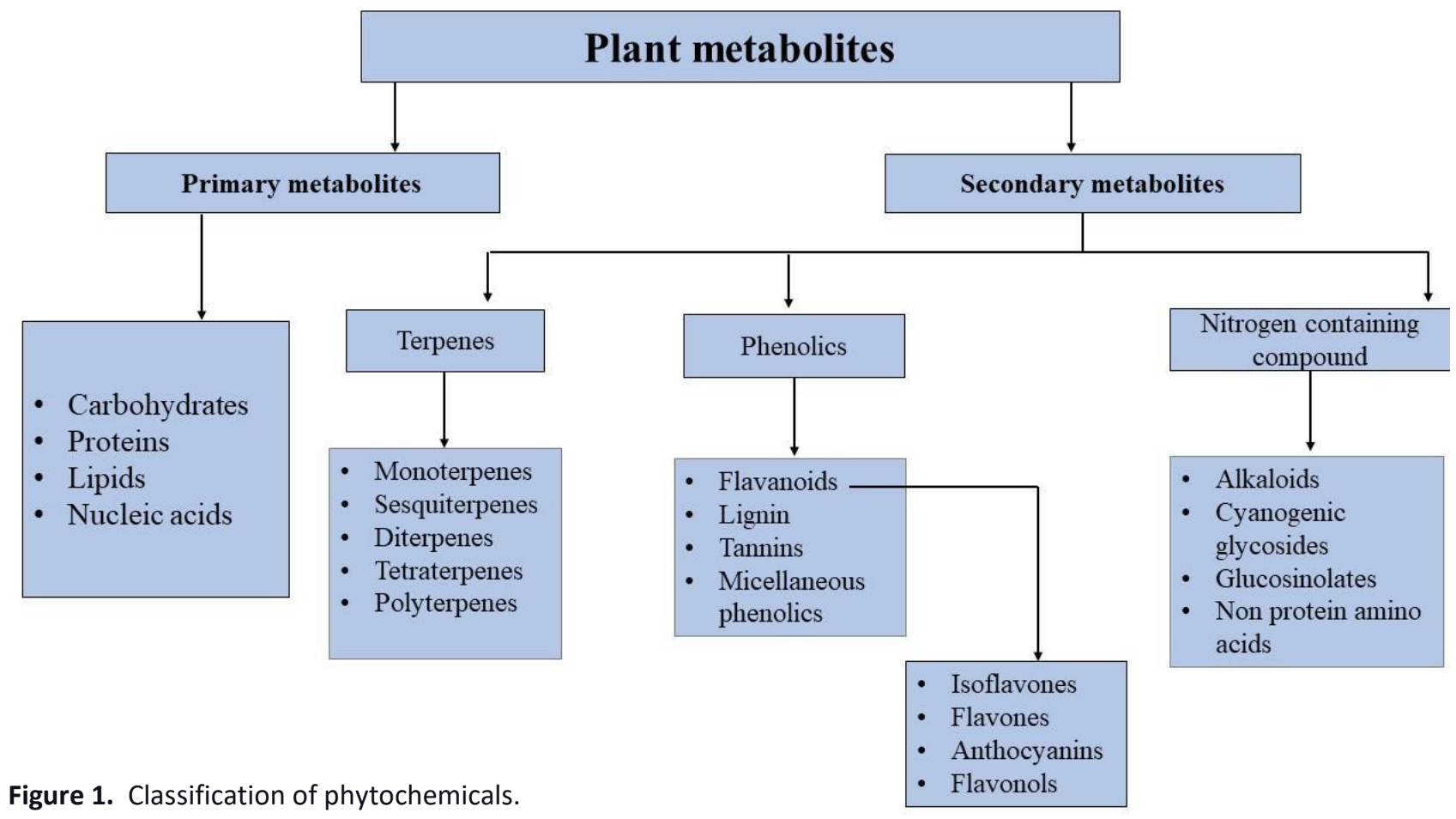


lowering inflammation, LDL cholesterol (LDL-C), and oxidative stress, respectively [100]. The most numerous and widely distributed category of bioactive molecules consists of polyphenols. Polyphenols are a complicated category of plant substances comprising one or more benzene rings and hydroxyl (OH), carbonyl (CO), and carboxylic acid $(\mathrm{COOH})$ groups in varying amounts. These usually occur with one or more sugar residues attached (that is, conjugated). Flavonoids are the most common class of polyphenols. Catechins, thearubingens, theaflavines, isoflavones, and more than eight thousand others are other forms of polyphenols.

Fruits, cereals, legumes, vegetables, nuts, tea, wine, and other drinks made from berries, vegetables, and grains are dietary sources of polyphenols and flavonoids. The content of polyphenols can differ significantly between food sources and within foods of the same kind [15]. Organosulfur compounds are commonly found in broccoli, cauliflower, other cruciferous vegetables such as brussels sprouts, and in allium vegetables such as garlic and leeks onions. In a cyclic or noncyclic structure, organosulfur compounds contain sulfur atoms bound to a cyanate group or a carbon atom $[45,108]$. The bioactive molecules of food products contain organosulfur compounds obtained once the vegetable has been damaged by cutting, chewing, or crushing. Through the action of myrosinase, different isothiocyanates are produced from glucosinolyates in cruciferous vegetables. In alliums, Allicin is formed from alliin and converted to diallyl sulfide/ diallyl disulfide/diallyl trisulfide by the action of enzyme alliinase. These hydrolytic breakdown products are the health-promoting bioactive food elements in both cruciferous and allium vegetables $[63,123]$.
In plants, phytosterols are the plant equivalents of cholesterol. Nevertheless, the structures are similar; the side-chain incorporates additional double bonds and methyl and ethyl groups in plant sterols. Campesterol, Beta-Sitosterol, and Stigmasterol are the most common bioactive phytosterols. Nuts, seeds, unrefined plant oils, and legumes are some of the best food sources. The saturated plant sterol derivatives are plant stanols, with sitostanol being the most common. Plant stanols occur naturally in soybean oil, wood pulp, and tall oil but are most commonly obtained in the diet by chemical hydrogenation of plant sterols. [87, 68].

Carotenoids are lipid-soluble plant pigments that contain approximately forty carbons and an extensive conjugated double bond system, both oxygenated or non-oxygenated hydrocarbons. The dominant non-polar bioactive carotenoids are betacarotene, alpha-carotene, and lycopene. Lutein is the primary bioactive polar carotenoid. It is possible to find carotenoids esterified into fatty acids or unesterified in plant tissue. Good lutein sources are spinach, carrots, squash, sweet potato, and abundant in dark green leafy vegetables such as kale, spinach, mustard greens, and green beans. Lycopene is primarily present in tomatoes [110]. The whole fruit and vegetable carotenoid content varies with the age and storage condition of vegetables [91]. Tocopherols and tocotrienols are bioactive lipid-soluble compounds that contain a phenolic-chromanol ring connected to a saturated or unsaturated isoprenoid side chain [107]. Based on the number and location of methyl groups, mainly four primary forms of alpha, beta, gamma, and delta tocopherols and tocotrienols, are found in which the phenolic-chromanol ring varies. Furthermore, at positions 2,4 , and 8 of the 
isoprenoid side chain, tocopherols have three asymmetrical carbons. Therefore, there are eight isomeric types of tocopherols, of which RRR-atocopherol has the most significant bioactivity in human blood and tissues and is also the most abundant Vegetable oils are familiar dietary sources of both tocopherol and tocotrienols, nuts and the germ part [16].

Biological Actions and role in Therapeutics: The exact biological mechanism of how plant-based bioactive food components impart health-promoting benefits significantly lacks understanding. Bioactive food components function at different or similar target sites simultaneously. It has been shown that bioactive food ingredients can reduce the risk of cancer, cardiovascular disease, osteoporosis, and infection [67]. In different phases of diseases, bioactive food components have health-promoting functions that are correlated with multiple progressive steps, from initiation to progress. For instance, in cardiovascular diseases, isoflavones can decrease circulating oxidized low-density plasma lipoproteins via binding cholesterol in the intestinal tract. Also, it decreases dietary cholesterol absorption, increases bile excretion, decreases endogenous cholesterol levels, and modulates arterial elasticity, thus improving blood vessel dilation and constriction responses [92, 102].

Inflammation is one of the foremost reasons for various acute or chronic pathological conditions. Epidemiological studies reveal that dietary patterns, foods, and bioactive compounds in spices and herbs can prevent inflammation, leading to carcinogenesis or cardiovascular diseases through their antioxidant and anti-inflammatory properties [58, 111]. Free radicals and reactive oxygen species are quenched by polyphenols, carotenoids, tocopherols, and allyl sulfides. Free radicals have a carbon or oxygen atom which is extremely unstable and has an unpaired electron. Anti-oxidants' primary activities include the regulation of the redox potential and the depletion of the potential carcinogenesis initiators. Redox modifications within a cell can cause different molecular responses, including apoptosis induction (cell death) and signal transduction activation. Therefore, in promoting health and disease prevention, redox and anti-oxidant control of physiological and pathological processes are essential. Many bioactive components are capable of binding to intestinal tract toxins or carcinogens, thus preventing transfer or absorption, like binding polyphenols in tea to $\mathrm{N}$-nitroso compounds in the intestinal tract [117]. The dietary fiber and phytosterol/stanols have a lipid-lowering effect by sequestering cholesterol in the intestinal tract and reducing cholesterol absorption. Moreover, dietary fibers trap the harmful toxins and carcinogens in the tract [19].

Due to the structural similarity between some isoflavone and estradiol metabolites, the estrogen metabolite indicates the chance of similar biological activity to estrogen. However, isoflavones or phytoestrogens display estrogen's antagonistic activity, resulting in lower average sensitivity in premenopausal women to estrogen and reducing the risk of breast cancer $[20,106]$. In postmenopausal women, hormone-sensitive surges in plasma cholesterol levels and bone loss can be reduced by incorporating phytoestrogen-rich diets $[92,102]$. The multiple anti-oxidant potentials of polyphenols, tocopherols, carotenoids, isothiocyanates, and allyl 
sulfides are the primary immune modulation mechanisms. These compounds can minimize the harmful effects of reactive oxygen species and free radicals, contributing to premature immune cell death [16]. It has also been shown that bioactive food components promote the phagocytic activity of macrophages and the development of many forms of immune cells, thus increasing disease resistance. Garlic, broccoli, onions, vegetable oils, almonds, walnuts, and others mentioned are among the foods that have been shown to have beneficial immunomodulatory effects (Table 1).

Table 1. Common Food Sources from plants with Their Bioactive Components and Biological Functions.

\begin{tabular}{|c|c|c|c|}
\hline Food item & Bioactive Compound & Function & Reference \\
\hline $\begin{array}{l}\text { Broccoli, Cauliflower, Brussels } \\
\text { Sprouts, Garlic, Onions }\end{array}$ & $\begin{array}{l}\text { Glucosinolates, Diallyl } \\
\text { Sulfides, Isothiocyanates. }\end{array}$ & $\begin{array}{l}\text { Antimicrobial, Immunomodulator, Anticancer, } \\
\text { Detoxification. }\end{array}$ & {$[47,75]$} \\
\hline Wheat & $\begin{array}{l}\text { Wheat Gluten Derived } \\
\text { Immunopeptides }\end{array}$ & Increased Natural Killer Cell Activity. & {$[44]$} \\
\hline $\begin{array}{l}\text { Whole Grains,Oats, } \\
\text { Fresh Fruit With Skin }\end{array}$ & Dietary Fiber & Lipid-Lowering Action & {$[4]$} \\
\hline $\begin{array}{l}\text { Grapes, Red Wine, Tea, Fresh } \\
\text { Fruits, and Vegetables }\end{array}$ & $\begin{array}{l}\text { Isoflavonoids and } \\
\text { Polyphenols. }\end{array}$ & $\begin{array}{l}\text { Antioxidant, Lipid- Lowering, Immunomodulator, } \\
\text { Antiosteoporotic, Anticancerous. }\end{array}$ & {$[9,23,128]$} \\
\hline $\begin{array}{l}\text { Soybean and Soybased } \\
\text { Products, Flaxseed, Cabbage, } \\
\text { Legumes, Tea }\end{array}$ & $\begin{array}{l}\text { Phytoestrogens (Genistein, } \\
\text { Daidzein). }\end{array}$ & $\begin{array}{l}\text { Anticancerous Antiestrogen, } \\
\text { Anti- Osteoporotic, Antiproliferative. }\end{array}$ & {$[49,120]$} \\
\hline Coconut & $\begin{array}{l}\text { Trglyceridess } \\
\text { Phytosterols }\end{array}$ & $\begin{array}{l}\text { Antihelminthic, Anti-Inflammatory, } \\
\text { Antinociceptive, Antioxidant, Antifungal, } \\
\text { Antimicrobial, Antitumor, Analgesic, Antiarthritic, } \\
\text { Antibacterial, } \\
\text { Antipyretic,AntidiarrhealHypoglycemic. } \\
\text { Cardioprotective, Antiseizure, cytotoxicity, } \\
\text { Hepatoprotective, Vasodilation, Nephroprotective, } \\
\text { and Anti-Osteoporosis Effects. }\end{array}$ & $\begin{array}{l}{[7,50,54,} \\
85]\end{array}$ \\
\hline Vegetable Oil, Nuts, Seeds & $\begin{array}{l}\text { Tocopherols and Tocotrienols, } \\
\text { Phytosterols }\end{array}$ & Antioxidant, Immunomodulator, Lipid Lowering & {$[101,114]$} \\
\hline $\begin{array}{l}\text { Carrots, Corn, Squash, Green } \\
\text { Leafy Vegetables, Oranges, } \\
\text { Papaya, Red Palm Oil }\end{array}$ & Carotenoids & Antioxidant Immunomodulators. & {$[82]$} \\
\hline Green Leafy Vegetables & Lutein & Reduction in Age-Related Macular Degeneration & [31] \\
\hline $\begin{array}{l}\text { Chlorella } \\
\text { Vulgarian }\end{array}$ & $\begin{array}{l}\text { Uncharacterized Peptides Of } \\
\text { Molecular Weight 2e5 Kda }\end{array}$ & $\begin{array}{l}\text { Stimulation Of Humoral Immune Functions, } \\
\text { Haemopoiesis, Monocyte-Macrophage System } \\
\text { Activation }\end{array}$ & {$[80]$} \\
\hline Tomatoes & Lycopene & Antiproliferative, Anticancer & {$[86]$} \\
\hline Garlic & Allicin, Ajoene & $\begin{array}{l}\text { Antimicrobial, Anticancer } \\
\text { Lowers bad Cholesterol; } \\
\text { Antibiotic and Anti-Static Properties, }\end{array}$ & {$[6,69]$} \\
\hline
\end{tabular}




\begin{tabular}{|c|c|c|c|}
\hline Food item & Bioactive Compound & Function & Reference \\
\hline $\begin{array}{l}\text { Njavara Rice } \\
\text { (Oryza Sativa Linn) }\end{array}$ & $\begin{array}{l}\text { Alkaloids, phenolic } \\
\text { compounds,essential oils, } \\
\text { aromatic carbons, } \\
\text { monounsaturated omega } 9 \\
\text { fatty acids, fatty alcohol, } \\
\text { polyterpenes, esters and } \\
\text { volatile compounds }\end{array}$ & $\begin{array}{l}\text { Hepato Protective Antispasmodic, AntiRheumatic, } \\
\text { Anti Inflammatory, Hypocholesterolemic, Cancer } \\
\text { Preventive, Nematicide, Antihistaminic,, } \\
\text { Antiarthritic, Anticoronary, Antieczemic, Antiacne, } \\
\text { 5-Alpha Reductase Inhibitor } \\
\text { And Antiandrogenic Activities. }\end{array}$ & {$[14,76]$} \\
\hline Turmeric & Curcuminoids & $\begin{array}{l}\text { Anti-inflammatory, Antioxidant, Anticarcinogenic, } \\
\text { Antimutagenic, Anticoagulant, Antifertility, } \\
\text { Antidiabetic, Antibacterial, Antifungal, } \\
\text { Antiprotozoal, Antiviral, Antifibrotic, Antivenom, } \\
\text { Antiulcer, Hypotensive Hypocholesteremic }\end{array}$ & {$[21,52]$} \\
\hline Fenugreek & $\begin{array}{l}\text { Vitexin, Isovitexin } \\
\text { Apigenin, Kaempferol } \\
\text { Caffeic acid Derivatives }\end{array}$ & $\begin{array}{l}\text { Antioxidant, Hypoglycaemic, Lipid lowering } \\
\text { activities }\end{array}$ & {$[56,83]$} \\
\hline Cinnamon & $\begin{array}{l}\text { Cinnamaldehyde And Several } \\
\text { Polyphenols, } \\
\text { Predominantly Proanthocyani } \\
\text { din And Catechins }\end{array}$ & antifungal, antibacterial, anti-inflammatory & {$[41,103]$} \\
\hline Ginger & Gingerols and Shogaols & $\begin{array}{l}\text { antioxidant, anti-inflammatory, antimicrobial, } \\
\text { anticancer, neuroprotective, cardiovascular } \\
\text { protective, respiratory protective, anti-obesity, } \\
\text { antidiabetic, antinausea, and antiemetic activities. }\end{array}$ & {$[72,105]$} \\
\hline Black Pepper & Piperine and piperidines & $\begin{array}{l}\text { Improves Digestibility. Antimicrobial Activity } \\
\text { Used for Treatment of Vertigo, Asthma, } \\
\text { Indigestion, Congestion, Fever, Diarrhoea. }\end{array}$ & {$[27,79]$} \\
\hline Lemon and Citrate Fruits & $\begin{array}{l}\text { Flavanoids } \\
\text { (Diosmin, Hesperidin, } \\
\text { Limocitrin), Vitamin C }\end{array}$ & $\begin{array}{l}\text { Antibacterial, Antifungal, Anti-Inflammatory, } \\
\text { Anticancer, Hepatoregenerating, Cardioprotective }\end{array}$ & {$[36,62]$} \\
\hline Honey & $\begin{array}{l}\text { Polyphenolic Gallic, Caffeic } \\
\text { acid, Coumaric Acids, } \\
\text { Flavonoids Pinocembrin, } \\
\text { Chrysin, Quercetin, Luteolin, } \\
\text { Apigenin, Abscisic Acid. }\end{array}$ & $\begin{array}{l}\text { Anti-bacterial, Anti-inflammatory, Antifungal, } \\
\text { Regenerative }\end{array}$ & [113] \\
\hline
\end{tabular}

Bioactive components from animal sources: Animals are abundant reservoirs of bioactive components that have a range of biological roles for human health. These bioactive molecules can be either vital to animals' survival or produced altogether to be more valuable to other organisms. Many natural animal origin compounds have been isolated, categorized, and used as nutritional or medicinal supplements to avoid, mitigate or cure different diseases and related symptoms [127]. These bioactive compounds promote various biological activities, such as antiinflammatory, antioxidant, cholesterol-lowering, activity. Besides their ability to provide calories and amino acids, dietary proteins have also provided 
health benefits in vivo and in vitro, either in an entire state or as hydrolysates. Food protein hydrolysates that cause beneficial biological functions are bioactive peptides. Bioactive peptides are generated through microbial fermentation, enzyme digestion, or enzyme proteolysis in vitro and may support major body systems' physiological activities [64]. These roles can include anti-oxidant, anti-microbial, antihypertensive, cytomodulatory, and immunomodulatory impact $[42,124]$.

\section{Biological Actions and role in Therapeutics:} Mammalian milk has various potent immunomodulatory peptides that influence immune function by suppressing or stimulating certain immune factors [32]. Bioactive peptides obtained from milk have possible additives in health-promoting functional foods. Bioactive peptides of whey proteins modulate both specific and non-specific immune responses [33]. Immunomodulatory peptides such as casein phosphopeptides and other casein-derived peptides are commercially available, stimulating immunoglobulin $\mathrm{A}(\operatorname{IgA})$ production in mice $[30,88]$. Gastrointestinal digestion releases many bioactive peptides from casein and whey proteins, including anti-bacterial, immunomodulatory, antihypertensive, and opioid peptides [34, 35, 74]. Various biological effects of peptides extracted from cow buffalo, horse, pig, and camel milk include antimicrobial, immune-modulatory, anti-oxidant oxidant, enzyme inhibitory, anti-thrombotic, and antagonistic activity against a range of toxic agents [77]. These bioactive peptides control diet-related medical conditions such as obesity, cardiovascular diseases, and many other metabolic diseases.
Marine fishes are another diverse source of bioactive compounds with a wide variety of novel bioactive substances. Peptides, sugars, lipids, and a wide range of vitamins and minerals are abundant in marine fish, and omega-3 fatty acids from fish and fish oil are essential among these [57]. A significant source of high-quality proteins, lipids, and many vitamins and minerals and their derivatives have various pharmacological activities, rendering fish an outstanding therapeutic food. Marine fish-derived bioactive peptides may have various biological functions, including inhibition of angiotensin-Iconverting enzyme (ACE), anti-oxidant, immunomodulatory, anti-microbial, and anticoagulant activities $[28,59]$. New technologies have made it simple to study a fish-based diet's medicinal role in treating coronary disorders, neurodegenerative diseases, and radical-mediated diseases. The cheapest animal protein substitute available on the market is Fish Protein Concentrate. Teleost. Fishes such as anchovies and mola are widely consumed in Asian countries, especially in lower milk consuming populations. Microbial or viral inhibitory peptide- 5e10 kDa peptide hydrolysates have been reported from Pacific oysters (Crassostrea Gigas), and the peptides demonstrated inhibition of the development of herpes [126]. Moreover, the involvement of IL-2 dependent immune deficiency, including AIDS, can be avoided or postponed by oyster protein extract [1].

Similarly, meat and meat products are rich in bioactive substances such as vitamins, minerals, peptides, and fatty acids, many of which are beneficial to human health. Meat is undeniably an excellent source of well-balanced essential amino acids, especially sulfate ones, as it contains an 
abundance of highly biologically essential proteins.

Meat is a perfect source of nutrients, including minerals and vitamins [8, 81]. Egg comprises several bioactive ingredients with pro-and/or antiinflammatory effects. The white fraction of eggs contains many bioactive proteins, including ovalbumin, ovotransferrin, ovomucin, lysozyme, and avidin [66]. These proteins have anti-bacterial and immunoprotective effects. Egg yolk-derived phosvitin has substantial bactericidal activity against E. coli [97]. When given orally, ovakinin, a biologically active peptide derivative of ovalbumin, has been shown to minimize blood pressure in spontaneously hypertensive rats. Some of the common Animals food Sources with their Bioactive Components and Functions are given in Table 2.

Table 2. Common Animals Food Sources with Their Bioactive Components and Functions.

\begin{tabular}{|c|c|c|c|}
\hline Food Item & Bioactive Compound & Function & Reference \\
\hline Milk & Whey Protein & $\begin{array}{l}\text { Modulation of both specific and non- } \\
\text { specific immune responses. }\end{array}$ & {$[33,74]$} \\
\hline $\begin{array}{l}\text { Milk And Fermented } \\
\text { Milk Products }\end{array}$ & $\begin{array}{l}\text { Bioactive Peptides: Lactoferrin, } \\
\text { Glycomacropeptide }\end{array}$ & $\begin{array}{l}\text { Immune System Enhancing, Anti } \\
\text { proliferative, Antimicrobial }\end{array}$ & [112] \\
\hline Fermented Milk Products & Probiotics & $\begin{array}{l}\text { Immunomodulators, Anticancer } \\
\text {,Antibacterial Anti-Oxidative } \\
\text { Gastrointestinal Health Modulators }\end{array}$ & {$[32]$} \\
\hline $\begin{array}{l}\text { Pacific Oysters } \\
\text { (Crassostrea Gigas) }\end{array}$ & $\begin{array}{l}\text { Peptide Hydrolysate } \\
\text { JCOE }\end{array}$ & $\begin{array}{l}\text { Herpes Virus Growth Inhibition } \\
\text { Properties }\end{array}$ & {$[1,59,126]$} \\
\hline Egg & $\begin{array}{l}\text { Phospholipids } \\
\text { Ovalbumin } \\
\text { Ovotransferrin, Ovomucin, } \\
\text { Lysozyme, and Avidin }\end{array}$ & $\begin{array}{l}\text { Antimicrobial, } \\
\text { Immunomodulatory, } \\
\text { Anti-Cancer, } \\
\text { And Anti-Hypertensive Activities }\end{array}$ & {$[66,97]$} \\
\hline Meat & $\begin{array}{l}\text { Vitamins, Minerals, Peptides, Fatty } \\
\text { Acids, ACE-Inhibitory Peptides }\end{array}$ & $\begin{array}{l}\text { Anti-Hypertensive, Anti Oxidant } \\
\text { Activities }\end{array}$ & {$[81,109]$} \\
\hline Fish & $\begin{array}{l}\text { Fatty Acids, Polysaccharides, } \\
\text { Polyether, Peptides, Proteins, } \\
\text { Enzymes And Lectins. Proteins }\end{array}$ & $\begin{array}{l}\text { Antihypertension, } \\
\text { Immunomodulatory, Antithrombotic, } \\
\text { Antioxidant, Anticancer And } \\
\text { Antimicrobial Activities }\end{array}$ & {$[60,57,129]$} \\
\hline
\end{tabular}

Therapeutic application of functional food: Bioactive compounds of food have a significant role in preventing and treating diseases since many of these compounds are involved in the pathophysiology of various disease developments. Several bioactive compounds are actively involved in the inflammation process, which is the cause of cancer, diabetes, and other inflammatory diseases. It has been reported that dietary habits, food ingredients, and bioactive compounds with anti-inflammatory properties are defensive. Thus, utilizing bioactive food compounds present in spices and herbs with anti-oxidant and anti-inflammatory properties may help prevent inflammation that can contribute to carcinogenesis or 
cardiovascular diseases [111]. For instance, dietary improvements and functional diets are the two most promising non-pharmaceutical treatments for inflammatory bowel disease (IBD). Probiotics and non-starchy polysaccharide supplements in the diet have proven to be effective in the treatment of IBD. Plant-derived extracts, phytochemicals, vitamins, and omega-3 fatty acids are forms of bioactive compounds. These functional foods and dietary peptides have potent anti-inflammatory effects both in animal models and humans [2]. Functional foods can modulate inflammatory cytokines and engage with the immune system to create anti-inflammatory effects. Polyphenolic constituents from cotoneaster are reported to have anti-oxidative and antiinflammatory activity, making it an ideal candidate for the preparation of nutraceuticals for inflammatoryrelated diseases [58]. Bioactive constituents from Coriandrum sativum are reported to have antihypertensive actions through their action mechanism as angiotensin-converting enzyme (ACE) inhibitors [48].

Phytochemicals from plants provide a promising new avenue for the development of diabetes mellitus therapeutics. Among these alkaloids, flavonoids, glycosides, terpenoids and steroids are more important [10]. Many fruits, vegetables, oil, legumes and nuts contain several potential phytochemicals with antidiabetic activities. These include mango, aloe vera, avocado, banana, bitter gourd, black tea, blueberry, coffee, cinnamon, garlic, ginger, grape, guava, jackfruit, olive oil, onion, papaya, pumpkin, pomegranate etc [11]. Dietary flavonoids mediate antidiabetic activity via modulating carbohydrate metabolism, beta-cell function, insulin sensitivity and functional availability of antioxidants [115].
Jackfruit (Artocarpus heterophyllus Lam) is a fruit crop that originated from South India well known for its medicinal properties. It contains various antioxidants that help prevent several chronic diseases, such as heart disease and diabetes. Jack fruit is reported to have a relatively low glycemic index (GI), preventing sudden hike in blood sugar level $[29,43]$. It is also a good source of vitamin C, carotenoids, and flavones, contributing to its antiinflammatory effect, reducing the risk of type 2 diabetes, hypertension, chronic heart diseases, and cancer $[24,51]$. The phytonutrients from jack fruit possess antioxidant, antihypertensive, antiulcer, anticancer, and anti-aging properties [70, 39]. Similarly, supplementation of Banana inflorescence (Musa paradisiaca) is reported to downregulate oxidative stress, hyperglycemia and inflammation in streptozotocin induced diabetic rats. In contrast, bioflavonoid morin exerts its antidiabetic effect through its insulin-mimetic effect [90].

Several antitumor compounds also have been identified among dietary phytochemicals. Another research study conducted by Yang et al. (2018) looked at the antitumor function [125] and structural properties of water-soluble polysaccharides from Kaempferia galanga (aromatic ginger). Wattanathorn et al. [118] reported the strengthened bone mineral density in menopausal women by a polyphenol-rich herbal congee containing a combination extract of Morus alba Polygonum odoratum leaves.

Bioactive compounds are also reported to possess neuroprotective effects. Parkinson's disease (PD), Alzheimer's disorder (AD), Prion disease, multiple sclerosis (MS), experimental autoimmune encephalomyelitis (EAE), ischemic stroke, and neuropathic pain are several of the disorders that can 
influence the brain. Many studies have suggested that the onset of Alzheimer's disease, age-related dementia, can be delayed or prevented by modifying lifestyle factors, including introducing an appropriate diet. Phenolic compounds, fat-soluble vitamins, isothiocyanates, omega-3 fatty acids, and carotenoids tend to be promising. These bioactive compounds act as anti-oxidants and anti-inflammatory agents, playing an active role in forming amyloid plaques and tau tangles [37]. Caryocar Brasiliense (Camb), a Caryocaraceae family member popularly known as "pequi," is a possible neuroprotective phytomedicine which possesses anti-oxidant and anti-cholinesterase activities as well as neuroprotective effects [25]. Bioactive components such as omega-3 fatty acids, plant sterol esters, and phenolic compounds can minimize the risk of atherosclerosis and cardiovascular diseases by decreasing inflammation, LDL cholesterol level and oxidative stress [100]. Thus, diets and functional foods will play a vital role in managing and preventing diseases.

\section{CONCLUSION}

Over the last decade, diets and functional foods have appeared as viable options for preventing and treating many diseases. Researchers are involved in bioactive peptides as a health-promoting functional food. In addition to meeting the body's nutritional needs, food proteins have been shown to have health benefits. Since patients' adherence to chronic drug prescriptions is notoriously low, minimizing drug doses or enhancing patient response to care is one choice that may effectively lead to early prevention. Bioactive components from food have been found to affect immune system parameters. Antihypertensive, anti-microbial, and immunomodulatory effects may be used to avoid or regulate lifestyle-related diseases, including hypertension, cancer, cardiovascular disease, diabetes, osteoporosis, stress, and obesity. This form of nutritional practice can be beneficial to both allergic and stable people who are affected. The use of bioactive substances in conjunction with medications tends to be a safe and successful way to delay cardiovascular diseases. However, information on bioactive food components' bioavailability and the appropriate dose necessary in humans is needed to maximize health benefits. Isolation and identification of these peptides and their pharmaco-dynamic parameters are required to transfer the powerful functional properties of food into clinical applications. Novel facilities such as innovative proteomics techniques, recombinant enzyme technology, and microbial fermentation have to be carried out to explore further.

List of abbreviations: n-3 FA: omega-3 fatty acids, PSE: plant sterol esters, PHC: phenolic compounds, LDL-C: LDL cholesterol, ACE: Angiotensin-I-converting enzyme, IBD:inflammatory bowel disease, PD: Parkinson's disease, AD: Alzheimer's disease, MS: multiple sclerosis, EAE: experimental autoimmune encephalomyelitis

Authors' contributions: Corresponding authors substantially contributed to the conception and draft of the article. All others participated in data collection and revised the article critically for important intellectual content.

Competing interests: The authors have no financial interests or conflicts of interests. 
Acknowledgment/funding: The authors declare no

acknowledgments or funding.

\section{REFERENCES}

1. Achour A, Lachgar A, Astgen A, Chams V, Bizzini B, Tapiero $H$, Zagury D: Potentialization of IL-2 effects on immune cells by oyster extract (JCOE) in normal and HIV-infected individuals. Biomedicine \& pharmacotherapy. 1997, 51(10):427-9.

2. Al Mijan M, Lim BO: Diets, functional foods, and nutraceuticals as alternative therapies for inflammatory bowel disease: Present status and future trends. World journal of gastroenterology. 2018, 24(25):2673.

3. Ali AA, Abd Al Haleem EN, Khaleel SA, Sallam AS: Protective effect of cardamonin against acetic acidinduced ulcerative colitis in rats. Pharmacol Rep 2017, 69: 268-275.

4. Aller R, de Luis DA, Izaola O, La Calle F, del Olmo L, Fernandez L, Arranz T, Hernandez JG: Effect of soluble fiber intake in lipid and glucose levels in healthy subjects: a randomized clinical trial. Diabetes Research and Clinical Practice. 2004, 65(1):7-11.

5. American Cancer Society: Phytochemicals 2000. Available

[http://www.cancer.org/eprise/main/docroot/ETO/co ntent/ETO_5_3X_]

6. Ankri S, Mirelman D: Antimicrobial properties of allicin from garlic. Microbes and infection 1999, 1(2):125-129.

7. Anurag $\mathrm{P}$, Rajamohan $\mathrm{T}$ : Cardioprotective effect of tender coconut water in experimental myocardial infarction. Plant Foods for Human Nutrition 2003, 58(3):1-12.

8. Arihara $\mathrm{K}$, Ohata $\mathrm{M}$ : Bioactive compounds in meat. InMeat biotechnology; 2008:231-249.

9. Ateba SB, Mvondo MA, Djiogue S, Zingué S, Krenn L, Njamen D: A pharmacological overview of alpinumisoflavone, a natural prenylated isoflavonoid. Frontiers in pharmacology 2019, 10:952.

10. B Gaikwad S, Krishna Mohan G, Sandhya Rani M: Phytochemicals for diabetes management. Pharmaceutical Crops 2014, 5(Suppl 1): 11-28

11. Beidokhti MN, Jäger AK: Review of antidiabetic fruits, vegetables, beverages, oils and spices commonly consumed in the diet. Journal of Ethnopharmacology 2017, 201:26-41.

12. Bioactive Food Components: Encyclopedia of Food and Culture. [Encyclopedia.com] Retrieved October 16, 2020.

13. Bitencourt MA, Silva HM, Abílio GM, Miranda GE, Moura AM, Araújo-Júnior JX, Silveira EJ, et al.: Antiinflammatory effects of methanolic extract of green algae Caulerpa mexicana in a murine model of ulcerative colitis. Reista Brasileira de Farmacognosia 2015, 25(6):677-682.

14. Boominathan M, Bakiyalakshmi SV: Analysis of bioactive compounds in navara (njavara) rice by gcms. International Journal of Recent Scientific Research 2016, 7(11):14307-14311.

15. Bravo L: Polyphenols: chemistry, dietary sources, metabolism, and nutritional significance. Nutrition reviews 1998, 56(11):317-333.
16. Brennan LA, Morris GM, Wasson GR, Hannigan BM, Barnett YA: The effect of vitamin $C$ or vitamin $E$ supplementation on basal and $\mathrm{H} 2 \mathrm{O} 2$-induced DNA damage in human lymphocytes. British Journal of Nutrition 2000, 84(2):195-202.

17. Britton G, Liaaen-Jensen S, Pfander $H$ (Eds.): Carotenoids: handbook. Birkhäuser 2012.

18. Camuesco D, Comalada M, Concha A, Nieto A, Sierra S, Xaus J, Zarzuelo A, et al.: Intestinal anti-inflammatory activity of combined quercitrin and dietary olive oil supplemented with fish oil, rich in EPA and DHA (n-3) polyunsaturated fatty acids, in rats with DSS-induced colitis. Clinical Nutrition 2006, 25:466-476. DOI: 10.1016/j.clnu.2005.12.009.

19. Capuano E: The behavior of dietary fiber in the gastrointestinal tract determines its physiological effect. Critical reviews in food science and nutrition 2017, 57(16):3543-3564.

20. Cassidy A, Bingham S, Setchell KD: Biological effects of a diet of soy protein rich in isoflavones on the menstrual cycle of premenopausal women. The American journal of clinical nutrition 1994, 60(3):333-40.

21. Chattopadhyay I, Biswas K, Bandyopadhyay U, Banerjee RK: Turmeric and curcumin: Biological actions and medicinal applications. Current science 2004, 10:44-53.

22. Chen PY, Shih NL, Hao WR, Chen CC, Liu JC, Sung LC: Inhibitory effects of momordicine I on high-glucoseinduced cell proliferation and collagen synthesis in rat cardiac fibroblasts. Oxidative medicine and cellular longevity. Volume 2018. Edited by de Oliveira FL. 2018.

23. Davalli P, Rizzi F, Caporali A, Pellacani D, Davoli S, Bettuzzi S, Brausi M, et al.: Anticancer activity of green tea polyphenols in prostate gland. Oxidative Medicine and Cellular Longevity. Volume 2012. Edited by Maraldi T. Hindawi; 2012.

24. de Faria AF, de Rosso VV, Mercadante AZ: Carotenoid composition of jackfruit (Artocarpus heterophyllus), determined by HPLC-PDA-MS/MS. Plant foods for human nutrition 2009, 64(2):108-15.

25. de Oliveira TS, Thomaz DV, da Silva Neri HF, Cerqueira LB, Garcia LF, Gil HP, Pontarolo R, et al: Neuroprotective effect of Caryocar brasiliense Camb. Leaves is associated with anticholinesterase and antioxidant properties. Oxidative medicine and cellular longevity. Volume 2018. Edited by de Oliveira FL. Hindawi; 2018.

26. Debnath T, Mijan MA, Kim DH, Jo JE, Kim YO, Lee JJ, Han JP, Lim BO. Anti-inflammatory effects of Haliotis discus hannai Ino on dextran sulfate sodium-induced colitis in mice. Journal of Food Biochemistry 2015, 39:209-217. DOI: $10.1111 /$ jfbc. 12118 .

27. Dorman HJ and Deans SG: Antimicrobial Agents From Plants: Antibacterial Activity Of Plant Volatile Oils. Journal Of Applied Microbiology 2000, 88: 308-316.

28. Elias RJ, Kellerby SS, Decker EA: Antioxidant activity of proteins and peptides. Critical reviews in food science and nutrition 2008, 48(5):430-441. DOI: 10.1080/10408390701425615.

29. Fernando MR, Wickramasinghe SN, Thabrew MI, Ariyananda PL, Karunanayake EH: Effect of Artocarpus heterophyllus and Asteracanthus longifolia on glucose tolerance in normal human subjects and in maturityonset diabetic patients. Journal of ethnopharmacology 1991, 31(3):277-82.

30. Ferraretto A, Signorile A, Gravaghi C, Fiorilli A, Tettamanti G: Casein phosphopeptides influence calcium uptake by cultured human intestinal HT-29 
tumor cells. The Journal of nutrition 2001, 131(6):165561.

31. Gale CR, Hall NF, Phillips DI, Martyn CN: Lutein and zeaxanthin status and risk of age-related macular degeneration. Investigative ophthalmology \& visual science 2003, 44(6):2461-2465.

32. Gauthier SF, Pouliot Y, Saint-Sauveur D: Immunomodulatory peptides obtained by the enzymatic hydrolysis of whey proteins. International dairy journal 2006, 16(11):1315-1323.

33. Gill HS, Doull F, Rutherfurd KJ, Cross ML: Immunoregulatory peptides in bovine milk. British Journal of Nutrition 2000, 84(S1):111-117.

34. Gobbetti M, Minervini F, Rizzello CG: Angiotensin Iconverting-enzyme-inhibitory and antimicrobial bioactive peptides. International Journal of Dairy Technology 2004, 57(2-3):173-188.

35. Gobbetti M, Stepaniak L, De Angelis M, Corsetti A, Di Cagno R: Latent bioactive peptides in milk proteins: proteolytic activation and significance in dairy processing. Critical reviews in food science and nutrition 2002, 42(3):223-39.

36. González-Molina E, Domínguez-Perles R, Moreno DA, García-Viguera C: Natural bioactive compounds of citrus limon for food and health. Journal of pharmaceutical and biomedical analysis. 2010, 51(2):327-345.

37. Grodzicki W, Dziendzikowska K: The role of selected bioactive compounds in the prevention of Alzheimer's disease. Antioxidants 2020, 9(3):229.

38. Gunness P, Gidley MJ: Mechanisms underlying the cholesterol-lowering properties of soluble dietary fibre polysaccharides. Food and function 2010, 1(2):149-55.

39. Gupta AK, Tandon N: Reviews on Indian Medicinal Plants. Volume 3. Indian Counsel of Medical Research; 2004.

40. Hahn NI: Are phytoestrogens nature's cure for what ails us? A look at the research. Journal of the Academy of Nutrition and Dietetics 1998, 98(9):974-6.

41. Hameed $\mathrm{IH}$, Altameme $\mathrm{HJ}$, and Mohammed GJ: Evaluation of antifungal and antibacterial activity and analysis of bioactive phytochemical compounds of Cinnamomum zeylanicum (Cinnamon bark) using gas chromatography-mass spectrometry. Oriental Journal of Chemistry 2016, 32(4):1769.

42. Hartmann R, Meisel H: Food-derived peptides with biological activity: from research to food applications. Current opinion in biotechnology 2007, 18(2):163-169.

43. Hettiaratchi UP, Ekanayake S, Welihinda J: Nutritional assessment of a jackfruit (Artocarpus heterophyllus) meal. Ceylon Medical Journal 2011, 56(2).

44. Horiguchi N, Horiguchi $H$, Suzuki Y: Effect of wheat gluten hydrolysate on the immune system in healthy human subjects. Bioscience, biotechnology, and biochemistry 2005, 69(12):2445-2449.

45. Howard LA, Jeffery EH, Wallig MA, Klein BP: Retention of phytochemicals in fresh and processed broccoli. Journal of food science 1997, 62(6):1098-1104.

46. Hsiang CY, Lo HY, Huang HC, Li CC, Wu SL, Ho TY: Ginger extract and zingerone ameliorated trinitrobenzene sulphonic acidinduced colitis in mice via modulation of nuclear factor-KB activity and interleukin- $1 \beta$ signalling pathway. Food Chem 2013, 136: 170-177. DOI: 10.1016/j.foodchem.2012.07.124.

47. Huang MT, Ferraro T, Ho CT: Cancer chemoprevention by phytochemicals in fruits and vegetables: an overview. AGRIS. Edited by Huang MT, Ho OC, Rosen RT. 1994:2-16.

48. Hussain F, Jahan N, Rahman KU, Sultana B, Jamil S: Identification of Hypotensive Biofunctional Compounds of Coriandrum sativum and Evaluation of Their Angiotensin-Converting Enzyme (ACE) Inhibition Potential. Oxidative medicine and cellular longevity; 2018(3):1-11

49. Hwang KA, Choi KC: Anticarcinogenic effects of dietary phytoestrogens and their chemopreventive mechanisms. Nutrition and cancer 2015, 67(5):796-803.

50. Intahphuak $S$, Khonsung $P$, Panthong $A$ : Antiinflammatory, analgesic, and antipyretic activities of virgin coconut oil. Pharmaceutical biology 2010, 48(2):151-7.

51. Jagtap UB, Panaskar SN, Bapat VA: Evaluation of antioxidant capacity and phenol content in jackfruit (Artocarpus heterophyllus Lam.) fruit pulp. Plant foods for human nutrition 2010, 65(2):99-104.

52. Jayarathne S, Koboziev I, Park OH, Oldewage-Theron W, Shen $\mathrm{CL}$, Moustaid-Moussa N: Anti-inflammatory and anti-obesity properties of food bioactive components: effects on adipose tissue. Preventive nutrition and food science 2017, 22(4):251.

53. Jiang $X$, Teng $S$, Wang $X$, Li S, Zhang $Y$, Wang $D$ : The Antidiabetic and Antinephritic Activities of Tuber melanosporum via Modulation of Nrf2-Mediated Oxidative Stress in the $\mathrm{db} / \mathrm{db}$ Mouse. Oxidative medicine and cellular longevity. Volume 2018. Edited by Teodoro AJ. Hindawi; 2018.

54. Jose SP, Asha $S$, Krishnakumar IM, Ratheesh $M$, Santhosh S, Sandya S, Kumar G, et al.: Nephroprotective effect of a novel formulation of unopened coconut inflorescence sap powder on gentamicin induced renal damage by modulating oxidative stress and inflammatory markers. Biomedicine \& Pharmacotherapy 2017, 85:128-135.

55. Kamali $\mathrm{M}$, Tavakoli $\mathrm{H}$, Khodadoost $\mathrm{M}$, Daghaghzadeh $\mathrm{H}$, Kamalinejad M, Gachkar L, Mansourian M, et al.: Efficacy of the Punica granatum peels aqueous extract for symptom management in ulcerative colitis patients. A randomized, placebo controlled, clinical trial. Complement Ther Clin Pract 2015, 21(3): 141-146. DOI: 10.1016/j.ctcp.2015.03.001.

56. Khole $\mathrm{S}$, Chatterjee $\mathrm{S}$, Variyar $\mathrm{P}$, Sharma A, Devasagayam TP, Ghaskadbi S: Bioactive constituents of germinated fenugreek seeds with strong antioxidant potential. Journal of functional foods 2014 , 6:270-279.

57. Khora SS. Marine fish-derived bioactive peptides and proteins for human therapeutics. International Journal of Pharmacy and Pharmaceutical Sciences 2013, 5(3):31-37.

58. Kicel A, Kolodziejczyk-Czepas J, Owczarek A, Rutkowska M, Wajs-Bonikowska A, Granica S, Nowak P: Multifunctional phytocompounds in Cotoneaster fruits: Phytochemical profiling, cellular safety, antiinflammatory and antioxidant effects in chemical and human plasma models in vitro. Oxidative medicine and cellular longevity. Volume 2018. Edited by de Oliveira FL. Hindawi; 2018.

59. Kim SK, Ravichandran YD, Khan SB, Kim YT: Prospective of the cosmeceuticals derived from marine organisms. Biotechnology and Bioprocess Engineering 2008, 13(5):511-523. 
60. Kim SK, Wijesekara I. Development and biological activities of marine-derived bioactive peptides: A review. Journal of Functional foods 2010, 2(1):1-9.

61. King AM, Young G: Characteristics and occurrence of phenolic phytochemicals. Journal of the American Dietetic Association 1999, 99(2):213-8.

62. Klimek-Szczykutowicz M, Szopa A, Ekiert H: Citrus limon (Lemon) Phenomenon-A Review of the Chemistry, Pharmacological Properties, Applications in the Modern Pharmaceutical, Food, and Cosmetics Industries, and Biotechnological Studies. Plants 2020, 9(1):119.

63. Klotzbach-Shimomura K: Functional foods: The role of physiologically active compounds in relation to disease. Topics in Clinical Nutrition 2001, 16(2):68-78.

64. Korhonen $\mathrm{H}$, Pihlanto A: Bioactive peptides: Production and functionality. International Dairy Journal, 2006, 16(9):945-960.

65. Korhonen $\mathrm{H}$, Pihlanto $\mathrm{A}$ : Food-derived bioactive peptides-opportunities for designing future foods. Current Pharmaceutical Design, 2003, 9(16):1297-1308.

66. Kovacs-Nolan J, Phillips M, Mine Y: Advances in the value of eggs and egg components for human health. Journal of Agricultural and Food Chemistry 2005, 53(22):8421-3.

67. Kris-Etherton PM, Hecker KD, Bonanome A, Coval SM, Binkoski $A E$, Hilpert KF, Griel $A E$, et al.: Bioactive compounds in foods: their role in the prevention of cardiovascular disease and cancer. The American Journal of Medicine 2002, 113(9):71-88.

68. Lagarda MJ, García-Llatas G, Farré R: Analysis of phytosterols in foods. Journal of Pharmaceutical and Biomedical Analysis 2006, 41(5):1486-1496.

69. Ledezma E, Apitz-Castro R: Ajoene the main active compound of garlic (Allium sativum): a new antifungal agent. Revista Iberoamericana de Micologia 2006, 23(2):75-80

70. Lin JA, Wu CH, Fang SC, Yen GC: Combining the observation of cell morphology with the evaluation of key inflammatory mediators to assess the antiinflammatory effects of geranyl flavonoid derivatives in breadfruit. Food Chemistry 2012,132(4):2118-2125.

71. Liu L, Liu YL, Liu GX, Chen X, Yang K, Yang YX, Xie Q, et al.: Curcumin ameliorates dextran sulphate sodiuminduced experimental colitis by blocking STAT3 signaling pathway. International Immunopharmacology 2013, 17:314-320. DOI: 10.1016/j.intimp.2013.06.020.

72. Mao QQ, Xu XY, Cao SY, Gan RY, Corke H, Li HB: Bioactive compounds and bioactivities of ginger (Zingiber officinale Roscoe). Foods 2019, 8(6):185.

73. Mathai K: Nutrition in the adult years. Krause's Food, Nutrition, and Diet Therapy. 10th edition. Edited by LK Mahan and S Escott-Stump. 2000, 271:274-275.

74. Meisel H, FitzGerald RJ: Biofunctional peptides from milk proteins: mineral binding and cytomodulatory effects. Current Pharmaceutical Design 2003, 9(16):1289-1296.

75. Miękus N, Marszałek K, Podlacha M, lqbal A, Puchalski C, Świergiel AH: Health Benefits of Plant-Derived Sulfur Compounds, Glucosinolates, and Organosulfur Compounds. Molecules 2020, 25(17):3804.

76. Mohanlal S, Parvathy R, Shalini V, Helen A, Jayalekshmy $A$ : Isolation, characterization and quantification of tricin and flavonolignans in the medicinal rice Njavara (Oryza sativa L.), as compared to staple varieties. Plant Foods for Human Nutrition 2011, 66(1):91-96.
77. Mohanty DP, Mohapatra S, Misra S, Sahu PS: Milk derived bioactive peptides and their impact on human health-A review. Saudi Journal of Biological Sciences 2016, 23(5):577-583.

78. Moorachian ME: Phytochemicals: Why and How? Tastings 2000, 7:4-5.

79. Moorthy M, Ravikumar S, Viswanathan K, and Edwin SC: Ginger, Pepper and Curry Leaf Powder as Feed Additives in Broiler Diet: International Journal of Poultry Science 2009, 8:779-782. DOI: 10.1016/j.pharep.2016.11.002.

80. Morris HJ, Carrillo OV, Almarales Á, Bermúdez RC, Alonso ME, Borges L, Quintana MM, et al.: Protein hydrolysates from the alga Chlorella vulgaris $87 / 1$ with potentialities in immunonutrition. Biotecnología Aplicada 2009, 26(2):162-165.

81. Mulvihill, B: Human Nutrition| Micronutrients in Meat. Encyclopedia of Meat Sciences (Second Edition); 2004:618-623.

82. Nabi F, Arain MA, Rajput N, Alagawany M, Soomro J, Umer $M$, Soomro $F$, et al.: Health benefits of carotenoids and potential application in poultry industry: A review. Journal of Animal Physiology and Animal Nutrition 2020, 104(6):1809-1818.

83. Naidu MM, Shyamala BN, Naik JP, Sulochanamma G, Srinivas $P$ : Chemical composition and antioxidant activity of the husk and endosperm of fenugreek seeds. LWT-Food Science and Technology 2011, 44(2):451456.

84. Nakano Y, Ando K, Nakamura S, Hirata M, Yoshida T, Matunaga I, Oda H: Relationships between LifestyleRelated Factors and Immune Parameters in MiddleAged Male Workers. Journal of Occupational Health 2001, 43(6):321-330.

85. Oliveira LM, Bevilaqua CM, Costa CT, Macedo IT, Barros RS, Rodrigues AC, Camurça-Vasconcelos AL et al.: Anthelmintic activity of Cocos nucifera L. against sheep gastrointestinal nematodes. Veterinary Parasitology 2009, 159(1):55-59.

86. Ono M, Takeshima M, Nakano S: Mechanism of the anticancer effect of lycopene (tetraterpenoids). The Enzymes 2015, 37:139-166.

87. Ostlund Jr RE: Phytosterols in human nutrition. Annual Review of Nutrition 2002, 22(1):533-549.

88. Otani H, Nakano K, Kawahara T: Stimulatory effect of a dietary casein phosphopeptide preparation on the mucosal IgA response of mice to orally ingested lipopolysaccharide from Salmonella typhimurium. Bioscience, Biotechnology, and Biochemistry 2003, 67(4):729-735

89. Oz AT, Kafkas E: Phytochemicals in fruits and vegetables. Waisundara V. Superfood and functional food. London: IntechOpen; 2017:175-184.

90. Paoli P, Cirri P, Caselli A, Ranaldi F, Bruschi G, Santi A, Camici G: The insulin-mimetic effect of Morin: A promising molecule in diabetes treatment. Biochimica et Biophysica Acta (BBA)-General Subjects 2013, 1830(4):3102-3111.

91. Parker RS: Phytochemicals: Carotenoids. In Wiley Encyclopedia of Food Science and Technology. Volume 3. 2nd edition. Edited by FJ Francis. New York: John Wiley and Sons; 2000:1909-1915.

92. Potter SM, Baum JA, Teng H, Stillman RJ, Shay NF, Erdman Jr JW: Soy protein and isoflavones: their effects on blood lipids and bone density in postmenopausal women. The American Journal of Clinical Nutrition 1998, 68(Suppl 6):1375S-1379S. 
93. Preetha PP, Devi VG, Rajamohan T: Antihyperlipidemic effects of mature coconut water and its role in regulating lipid metabolism in alloxan-induced experimental diabetes. Comparative Clinical Pathology. 2014, 23(5):1331-1337.

94. Renjith RS, Chikku AM, Rajamohan T. Cytoprotective, antihyperglycemic and phytochemical properties of Cocos nucifera (L.) inflorescence. Asian Pacific Journal of Tropical Medicine 2013, 6(10):804-810.

95. Salil G, Nevin KG, Rajamohan T: Arginine rich coconut kernel protein modulates in alloxan treated rats. Chemico-Biological Interactions 2001, 189:107-111.

96. Sandhya VG, Rajamohan T: Beneficial effects of coconut water feeding on lipid metabolism in cholesterol-fed rats. Journal of Medicinal Food 2006, 9(3):400-407.

97. Sattar Khan MA, Nakamura S, Ogawa M, Akita E, Azakami H, Kato A: Bactericidal action of egg yolk phosvitin against Escherichia coli under thermal stress. Journal of Agricultural and Food Chemistry 2000, 48(5):1503-1506.

98. Saxena M, Saxena J, Nema R, Singh D, Gupta A: Phytochemistry of Medicinal Plants. Journal of Pharmacognosy and Phytochemistry 2013, 1(6).

99. Schwanke RC, Marcon R, Bento AF, Calixto JB. EPA- and DHA-derived resolvins' actions in inflammatory bowel disease. European Journal of Pharmacology 2016, 785: 156-164. DOI: 10.1016/ j.ejphar.2015.08.050.

100. Scolaro B, Soo Jin Kim H, de Castro IA: Bioactive compounds as an alternative for drug co-therapy: Overcoming challenges in cardiovascular disease prevention. Critical Reviews in Food Science and Nutrition 2018, 58(6):958-971.

101. Seppanen CM, Song $Q$, Saari Csallany A: The antioxidant functions of tocopherol and tocotrienol homologues in oils, fats, and food systems. Journal of the American Oil Chemists' Society 2010, 87(5):469-481.

102. Setchell KD, Cassidy A: Dietary isoflavones: biological effects and relevance to human health. The Journal of Nutrition 1999, 129(3):758S-67S.

103. Shan B, Cai YZ, Brooks JD, Corke H: Antibacterial properties and major bioactive components of cinnamon stick (Cinnamomum burmannii): activity against foodborne pathogenic bacteria. Journal of Agricultural and Food Chemistry 2007, 55(14):54845490.

104. Shapira S, Leshno A, Katz D, Maharshak N, Hevroni G, Jean- David M, Kraus S, et al.: Of mice and men: a novel dietary supplement for the treatment of ulcerative colitis. Therapeutic Advances in Gastroenterology 2017, 11: $1756283 \times 1774186$.

105. Shareef HK, Muhammed HJ, Hussein HM, Hameed IH: Antibacterial effect of ginger (Zingiber officinale) roscoe and bioactive chemical analysis using gas chromatography mass spectrum. Oriental Journal of Chemistry 2016, 32(2):20-40.

106. Shimizu H, Ross RK, Bernstein L, Pike MC, and Henderson BE: Serum Estrogen-Levels in Postmenopausal Women-Comparison of American Whites and Japanese in Japan. British Journal of Cancer 1990, 62 (3):451-453.

107. Shutu X, Dalong Z, Ye C, Yi Z, Shah T, Ali F, Qing L, et al.: Dissecting tocopherols content in maize (Zea mays L.), using two segregating populations and high-density single nucleotide polymorphism markers. BMC Plant Biology 2012, 12(1):1-4.
108. Song K, Milner JA: The influence of heating on the anticancer properties of garlic. The Journal of Nutrition 2001, 131(3):1054S-7S.

109. Stadnik J, Kęska P: Meat and fermented meat products as a source of bioactive peptides. Acta Scientiarum Polonorum Technologia Alimentaria 2015, 14(3):181190.

110. Stahl W, Sies H: Uptake of lycopene and its geometrical isomers is greater from heat-processed than from unprocessed tomato juice in humans. The Journal of Nutrition 1992, 122(11):2161-6.

111. Teodoro AJ: Bioactive compounds of food: their role in the prevention and treatment of diseases. Oxidative Medicine and Cellular Longevity. Volume 2019. Hindawi; 2019.

112. Uchiyama K, Nakamura M, Odahara S, Koido S, Katahira K, Shiraishi H, Ohkusa T: N-3 polyunsaturated fatty acid diet therapy for patients with inflammatory bowel disease. Inflammatory Bowel Diseases 2010, 16:16961707. DOI: 10.1002/ibd.21251.

113. Velásquez $P$, Montenegro $G$, Leyton $F$, Ascar $L$, Ramirez O, Giordano A: Bioactive compounds and antibacterial properties of monofloral Ulmo honey. CyTA-Journal of Food 2020, 18(1):11-19.

114. Vijaya C, Ramanathan M, Suresh B: Lipid lowering activity of ethanolic extract of leaves of Aegle marmelos (Linn.) in hyperlipidaemic models of Wistar albino rats. Indian Journal of Experimental Biology 2009, 47(3):182185.

115. Vinayagam R, Xu B: Antidiabetic properties of dietary flavonoids: a cellular mechanism review. Nutrition \& metabolism 2015, 12(1):1-20.

116. Wagner AE, Will $O$, Sturm C, Lipinski $S$, Rosenstiel $P$, Rimbach G: DSS-induced acute colitis in C57BL/6 mice is mitigated by sulforaphane pre-treatment. Journal of Nutritional Biochemistry 2013, 24:2085-2091. DOI: 10.1016/j.jnutbio.2013.07.009.

117. Wang ST, Cui WQ, Pan D, Jiang M, Chang B, Sang LX: Tea polyphenols and their chemopreventive and therapeutic effects on colorectal cancer. World Journal of Gastroenterology 2020, 26(6):562.

118. Wattanathorn J, Somboonporn W, Sungkamanee S, Thukummee W, Muchimapura S: A Double-Blind Placebo-Controlled Randomized Trial Evaluating the Effect of Polyphenol-Rich Herbal Congee on Bone Turnover Markers of the Perimenopausal and Menopausal Women. Oxidative Medicine and Cellular Longevity. Volume 2018. Edited by Teodoro AJ. Hindawi; 2018.

119. Wu S, Sun J, Tong Z, Lan X, Zhao Z, Liao D: Optimization of hydrolysis conditions for the production of angiotensin-I converting enzyme-inhibitory peptides and isolation of a novel peptide from lizard fish (Saurida elongata) muscle protein hydrolysate. Marine Drugs. 2012, 10(5):1066-1080.

120. Wuttke W, Jarry $H$, Westphalen S, Christoffel V, Seidlova-Wuttke D: Phytoestrogens for hormone replacement therapy? The Journal of Steroid Biochemistry and Molecular Biology 2002, 83(1-5):133147.

121. Xiao X, Kim J, Sun Q, Kim D, Park CS, Lu TS, Park Y: Preventive effects of cranberry products on experimental colitis induced by dextran sulphate sodium in mice. Food Chemistry 2015, 167:438-446. 
122. Yamamoto N, Ejiri M, Mizuno S: Biogenic peptides and their potential use. Current Pharmaceutical Design 2003, 9(16):1345-1355.

123. Yang CS, Chhabra SK, Hong JY, Smith TJ: Mechanisms of inhibition of chemical toxicity and carcinogenesis by diallyl sulfide (DAS) and related compounds from garlic. The Journal of Nutrition 2001, 131(3):1041S-5S.

124. Yang R, Zhang Z, Pei X, Han X, Wang J, Wang L, Long Z, et al.: Immunomodulatory effects of marine oligopeptide preparation from Chum Salmon (Oncorhynchus keta) in mice. Food Chemistry 2009, 113(2):464-470.

125. Yang $\mathrm{X}$, Ji $\mathrm{H}$, Feng $\mathrm{Y}, \mathrm{Yu}$ J, Liu A: Structural Characterization and Antitumor Activity of Polysaccharides from Kaempferia galanga L. Oxidative Medicine and Cellular Longevity. Volume 2018. Edited by Gil G. Hindawi; 2018.

126. Zeng M, Cui W, Zhao Y, Liu Z, Dong S, Guo Y: Antiviral active peptide from oyster. Chinese Journal of Oceanology and Limnology 2008, 26(3):307-312.

127. Zhang $X$, Chen F, Wang M: Bioactive Substances of Animal Origin. Handbook of Food Chemistry. Edited by Cheung $\mathrm{P}$ and Mehta B. Springer, Berlin, Heidelberg; 2015:1009.

128. Zheng YZ, Deng G, Guo R, Fu ZM, Chen DF: Theoretical insight into the antioxidative activity of isoflavonoid: The effect of the $\mathrm{C} 2=\mathrm{C} 3$ double bond. Phytochemistry 2019, 166:112075.

129. Zhu CF, Li GZ, Peng HB, Zhang F, Chen Y, Li Y: Treatment with marine collagen peptides modulates glucose and lipid metabolism in Chinese patients with type 2 diabetes mellitus. Applied Physiology, Nutrition, and Metabolism 2010, 35(6):797-804. 